\title{
MEANING OF FOREIGNERS AMONG ESTONIAN, LATVIAN, LITHUANIAN AND RUSSIAN UNIVERSITY STUDENTS
}

\author{
Kristi Kõiv ${ }^{1}$, Svetlana Gurieva ${ }^{2}$, Olga Deyneka ${ }^{3}$, Vaiva Zuzeviciute ${ }^{4}$, Anna Liduma ${ }^{5}$, \\ \& Sandra Rone ${ }^{5}$ \\ ${ }^{I}$ Institute of Education, University of Tartu (Estonia) \\ ${ }^{2}$ Department of Social Psychology, Saint Petersburg State University (Russia) \\ ${ }^{3}$ Political Psychology Department, Saint Petersburg State University (Russia) \\ ${ }^{4}$ Faculty of Public Security, Mykolas Romeris University (Lithuania) \\ ${ }^{5}$ Faculty of Education, University of Latvia (Latvia)
}

\begin{abstract}
The purpose of this pilot study was to explore how Estonia, Latvian, Lithuanian and Russian university students conceptualize the meaning of foreigners. The present study examines similarities and differences between Estonian $(\mathrm{N}=118)$, Latvian $(\mathrm{N}=101)$, Lithuanian $(\mathrm{N}=101)$, and Russian $(\mathrm{N}=92)$ university students' understandings about foreigners by self-reported open-ended questionnaire. The applied categorical quantitative analysis of the data was the basis for statistical analysis. Results revealed quite distinctive meanings associated with foreigners when comparing four samples' conceptualizations. The meaning of foreigners among university students was generally conceptualized in society level as an exclusion of people connected with different nationality and language, whereby Russian respondents empathized more differences in citizenship and three Baltic states respondents in attitudes and values. Overall acceptance or unacceptance of foreigners tended to depend on the level - foreigners were more accepted in personal level and unaccepted in society level. Additionally, all university students were generally open and tolerant toward foreigners in the area of individual differences evoked from cultural enrichment, but Latvian, Lithuanian and Russian students were more prone to accept foreigners when there was a mutual respect with common values, and Estonians expressed more the attitude about equality of people. University students in four study groups were generally agree, that foreigners have influenced them more positive than negative way, but reasons were different: Lithuanians empathize more sympathy and helping behavior; Estonian and Latvian more enlargement of knowledge's with increase of tolerance; and Russian students' opinions were more connected with undirect influence by means of media, art and literature.
\end{abstract}

Keywords: Concept of foreigners, attitudes towards foreigners, university students.

\section{Introduction}

In the last century, immigrants have entered Europe in large numbers, leading to a drastic change in demographic build-up (McLaren, 2003) and the population of foreigners in the countries of the European Union has risen sharply in recent years playing a dominant role in population growth in some countries (Organisation for Economic Co-operation and Development, 2012). The growth of immigration in Europe has been associated with an increase of anti-foreigner attitudes in a variety of European countries (Gang, Rivera-Batiz, \& Yun, 2013). Immigrants (or foreigners) are perceived not only as outsiders in their new societies but also as a threat to the social, political and economic order as well as a threat to the cultural homogeneity and the national identity of the state (e.g. Scheepers, Gijberts, $\&$ Coenders, 2002). The growing body of research on attitudes toward out-group populations in general and foreigners in European countries reveal that most people express negative attitudes toward foreigners (Gorodzeisky \& Semyonov, 2009). Also, it was reported more prejudice toward foreigners perceived as culturally dissimilar as toward more similar foreigners (Asbrock et al., 2014).

Previous researches (e.g. Gang et al., 2013; Ostapczuk, Musch, \& Moshagen, 2009) had showed that attitude toward foreigners were influenced by age and education: the more highly-educated and younger citizens tend to be more positive towards foreigners. Potential main reasons underlying the education effect include a different number of positive contacts with foreign people (Wagner, van Dick, Pettigrew, \& Christ, 2003) and an increased commitment to democratic norms of equality possibly associated with a higher formal education (Condran, 1979). Research had indicated that higher education is the key for decreasing attitudes towards minorities, but few studies (e.g. Kim, 2004; Sakai \& Koike, 
2011) have taken university students opinions into consideration. Due to this, university students were respondents of the present study in order to get their perspective on this matter.

In the era of globalization that accelerates personal and cultural exchanges across countries, understanding and respecting other cultures has become more important. This is true for the three Baltic countries (Kovalenko, 2010; Mensah, 2010; Leončikas \& Žibas, 20109 and Russia (Bisson, 2016) as these countries had experienced new migration views. For example, intolerance towards foreigners is a problem in three Baltic countries young people - surveys (e.g., Torney-Purta et al. 2001) suggest that in Estonia, Latvia and Lithuania adolescents hold relatively negative views towards foreigners, whereby in most of the European countries' respondents had positive attitudes about immigrants. When we look at previous studies among adults in three Baltic countries (Paas \& Halapuu, 2012) then we can identify differences in attitudes toward foreigners - Latvians and Estonians were less tolerant towards immigrants and Lithuanians were more tolerant. This rise a new research question: Is there similarities and differences between Estonian, Latvian, Lithuanian and Russian university students' conceptualization of the meaning of foreigners? The research is important because previous research (e.g. Hjerm, 2001; Ostapczik et al., 2009) had indicated that higher education is the key for influencing attitudes towards minorities.

The aim of the study was to explore how Estonia, Latvian, Lithuanian and Russian university students conceptualize the meaning of foreigners.

\section{Method}

\subsection{Samples}

Four samples of university students participated in the study: 118 Estonian (189 of them were women and 29 men), 101 Latvian (96 of them were women and 5 men), 101 Lithuanian (67 of them were women and $34 \mathrm{men}$ ), and 92 respondents (women 54 and $28 \mathrm{men}$ ). Totally, there were 412 respondents.

\subsection{Instrument}

Questionnaire consists of four open-ended questions expressing subjective feelings of acceptance and un-acceptance of foreigners in five areas: Meaning of foreigners (What do you understand by definition „, foreigners"?); reasons for acceptance of foreigners (Are you ready to accept foreigners or otherwise minded people? Why?); reasons for non-acceptance of foreigners (What would you never accept concerning with foreigners or otherwise minded people? Why?); and influence of foreigners (Have you been influenced by foreigners or otherwise minded people? How?).

Quantitative content analysis was used to code and analyze the open-ended questions answers categories. Chi-square was used to test for the differences between the three study groups responses categories calculated by percentages.

\section{Results}

The quantitative content analysis technique was used to categorize answers of open-ended question: What do you understand by definition of foreigners"? Table 1 shows findings among three samples of Baltic state university students as calculated as frequencies of key categories and between-group differences of categories analyzed by the $\chi^{2}$-test, whereby all differences were significant at $\mathrm{p}<.01$ level.

Table 1. Frequencies of key categories of descriptions of meaning of foreigners among four samples of students.

\begin{tabular}{|c|c|c|c|c|c|c|c|c|c|c|}
\hline Category & $\begin{array}{l}\text { Estonia } \\
(\mathrm{A})\end{array}$ & $\begin{array}{l}\text { Latvia } \\
\text { (B) }\end{array}$ & $\begin{array}{l}\text { Lithuania } \\
\text { (C) }\end{array}$ & $\begin{array}{l}\text { Russia } \\
\text { (D) } \\
\end{array}$ & $\begin{array}{l}\chi^{2} \\
\text { (A vs.B) }\end{array}$ & $\begin{array}{l}\chi^{2} \\
\text { (A vs.C) }\end{array}$ & $\begin{array}{l}\chi^{2} \\
\text { (A vs.D) }\end{array}$ & $\begin{array}{l}\chi^{2} \\
\text { B vs.C) }\end{array}$ & $\begin{array}{l}\chi^{2} \\
\text { (B vs.D) }\end{array}$ & $\begin{array}{l}\chi^{2} \\
(\mathrm{C} \text { vs.D })\end{array}$ \\
\hline $\begin{array}{l}\text { Different nationality } \\
\text { and language }\end{array}$ & $19 \%$ & $24 \%$ & $15 \%$ & $51 \%$ & ns & ns & 45.12 & $\mathrm{~ns}$ & 15.29 & 28.11 \\
\hline $\begin{array}{l}\text { Different } \\
\text { citizenship or no } \\
\text { citizenship }\end{array}$ & $2 \%$ & $6 \%$ & $4 \%$ & $28 \%$ & ns & ns & 78.82 & $\mathrm{~ns}$ & 54.78 & 56.76 \\
\hline $\begin{array}{l}\text { Poor economic } \\
\text { situation and } \\
\text { physical state }\end{array}$ & $6 \%$ & $7 \%$ & $30 \%$ & $4 \%$ & ns & 20.32 & ns & 15.03 & ns & 23.21 \\
\hline $\begin{array}{l}\text { Different attitudes } \\
\text { and values }\end{array}$ & $30 \%$ & $39 \%$ & $39 \%$ & $5 \%$ & ns & $\mathrm{ns}$ & 22.88 & $\mathrm{~ns}$ & 32.98 & 33.74 \\
\hline $\begin{array}{l}\text { Marginalization of } \\
\text { people: Different } \\
\text { life style }\end{array}$ & $12 \%$ & $14 \%$ & $11 \%$ & $11 \%$ & ns & ns & ns & $\mathrm{ns}$ & $\mathrm{ns}$ & $\mathrm{ns}$ \\
\hline $\begin{array}{l}\text { Individualistic } \\
\text { viewpoint }\end{array}$ & $30 \%$ & $11 \%$ & $2 \%$ & $1 \%$ & 13.35 & 27.87 & 23.53 & ns & $\mathrm{ns}$ & ns \\
\hline
\end{tabular}


Research results showed that four samples of students conceptualize foreigners mainly in society level: (1) differences in nationality and language, and (2) marginalization, whereby Russian students empathized more differences in nationality and language, and also differences in citizenship; and three Baltic counties students evaluated more differences in attitudes and values. Lithuanian university students conceptualize foreigners more often in terms of individual physical differences between people and Estonians expressed their own individualistic personal viewpoint by separating self from other groups of people.

An analyze of reasons for acceptance of foreigners among university students reveal overwhelming positive attitude toward foreigners with regards to emplacing several cultures are enriching people (Table 2). The reasons why young people in three Baltic countries accepted foreigners were different in personal level: (1) Estonian students were more prone to accept foreigners and otherwise minded people by expressing more often the attitude that all people are equal; (2) Latvian, Lithuanian and Russian students expressed more often the opinion to accept foreigners when there is a mutual respect, common values, moral and understandings between people.

Table 2. Frequencies of key categories of descriptions of reasons of acceptance of foreigners among four samples.

\begin{tabular}{|c|c|c|c|c|c|c|c|c|c|c|}
\hline Category & $\begin{array}{l}\text { Estonia } \\
\text { (A) }\end{array}$ & $\begin{array}{l}\text { Latvia } \\
\text { (B) }\end{array}$ & $\begin{array}{l}\text { Lithuania } \\
\text { (C) }\end{array}$ & $\begin{array}{l}\text { Russia } \\
\text { (D) }\end{array}$ & $\begin{array}{l}\chi^{2} \\
(\mathrm{~A} \text { vs.B) }\end{array}$ & $\begin{array}{l}\chi^{2} \\
\text { (A vs.C) }\end{array}$ & $\begin{array}{l}\chi^{2} \\
\text { (A vs.D) }\end{array}$ & $\begin{array}{l}\chi^{2} \\
\text { B vs.C) }\end{array}$ & $\begin{array}{l}\chi^{2} \\
\text { (B vs.D) }\end{array}$ & $\begin{array}{l}\chi^{2} \\
\text { (C vs.D) }\end{array}$ \\
\hline $\begin{array}{l}\text { Acceptance: Differences } \\
\text { enrich and are } \\
\text { interesting culturally }\end{array}$ & $31 \%$ & $28 \%$ & $30 \%$ & $31 \%$ & ns & ns & ns & ns & ns & ns \\
\hline $\begin{array}{l}\text { Acceptance: When there } \\
\text { is mutual respect, } \\
\text { common values } \\
\text { understanding }\end{array}$ & $14 \%$ & $32 \%$ & $36 \%$ & $36 \%$ & 8.05 & 4.05 & 4.08 & ns & ns & ns \\
\hline $\begin{array}{l}\text { Acceptance: When there } \\
\text { is no dangerous and } \\
\text { violent behaviour }\end{array}$ & $14 \%$ & $12 \%$ & $13 \%$ & $14 \%$ & ns & ns & ns & ns & ns & ns \\
\hline $\begin{array}{l}\text { Attitude: All people are } \\
\text { equal }\end{array}$ & $47 \%$ & $20 \%$ & $21 \%$ & $19 \%$ & 26.44 & 23.29 & 32.37 & ns & ns & ns \\
\hline
\end{tabular}

The third question in questionnaire was: What would you never accept concerning with foreigners or otherwise minded people? Results of analyze of reasons for non-acceptance of foreigners among three study samples is presents in the table 3. It was revealed that foreigners were less accepted on society level being not tolerant against aggression and violence, whereby three Baltic countries respondents tolerate less discrimination and religious extremism, and Russian compliance of cultural traditions and rules.

Table 3. Frequencies of key categories of descriptions of un-acceptance of foreigners among four samples.

\begin{tabular}{|c|c|c|c|c|c|c|c|c|c|c|}
\hline Category & $\begin{array}{l}\text { Estonia } \\
\text { (A) }\end{array}$ & $\begin{array}{l}\text { Latvia } \\
\text { (B) }\end{array}$ & $\begin{array}{l}\text { Lithuania } \\
\text { (C) }\end{array}$ & $\begin{array}{l}\text { Russia } \\
\text { (D) }\end{array}$ & $\begin{array}{l}\chi^{2} \\
\text { (A vs.B) }\end{array}$ & $\begin{array}{l}\chi^{2} \\
\text { (A vs.C) }\end{array}$ & $\begin{array}{l}\chi^{2} \\
\text { (A vs.D) }\end{array}$ & $\begin{array}{l}\chi^{2} \\
\text { B vs.C) }\end{array}$ & $\begin{array}{l}\chi^{2} \\
\text { (B vs.D) }\end{array}$ & $\begin{array}{l}\chi^{2} \\
\text { (C vs.D) }\end{array}$ \\
\hline $\begin{array}{l}\text { Society level: } \\
\text { Aggression and } \\
\text { violence }\end{array}$ & $28 \%$ & $22 \%$ & $24 \%$ & $30 \%$ & ns & $\mathrm{ns}$ & ns & ns & $\mathrm{ns}$ & ns \\
\hline $\begin{array}{l}\text { Society level: } \\
\text { Discrimination and } \\
\text { extremism }\end{array}$ & $49 \%$ & $56 \%$ & $50 \%$ & $17 \%$ & ns & ns & 18.63 & ns & 6.96 & 19.39 \\
\hline $\begin{array}{l}\text { Society level: People } \\
\text { do not follow cultural } \\
\text { traditions and rules } \\
\text { Group level: Sexual } \\
\text { minorities and } \\
\text { disabled }\end{array}$ & $17 \%$ & $20 \%$ & $23 \%$ & $35 \%$ & $\mathrm{~ns}$ & ns & 31.92 & ns & 36.73 & 27.85 \\
\hline
\end{tabular}

The last question in the questionnaire related to personal influence of foreigners: Have you been influenced by foreigners or otherwise minded people? Research result indicated that university students in four study groups had generally more positive than negative views toward foreigners connected with the influence on them, whereby negative feelings related to personal experiences about insecurity and unpredictable behavior and customs; and at the other side - foreigners as positive models as strong people who can survive and adapt in society. Reasons why foreigners can positively influence personally students were different: (1) Lithuanians emphasized more sympathy and helping behavior, (2) Estonians and Latvians more enlargement of their knowledges with an increase of tolerance towards foreigners as positive models, and (3) and Russian students' opinions were more connected with undirect positive influence by means of media, art and literature (Table 4). 
Table 4. Frequencies of key categories of personal descriptions of influence of foreigners among four samples.

\begin{tabular}{|c|c|c|c|c|c|c|c|c|c|c|}
\hline Category & $\begin{array}{l}\text { Estonia } \\
\text { (A) }\end{array}$ & $\begin{array}{l}\text { Latvia } \\
\text { (B) }\end{array}$ & $\begin{array}{l}\text { Lithuania } \\
\text { (C) }\end{array}$ & $\begin{array}{l}\text { Russia } \\
\text { (D) }\end{array}$ & $\begin{array}{l}\chi^{2} \\
\text { (A vs.B) }\end{array}$ & $\begin{array}{l}\chi^{2} \\
\text { (A vs.C) }\end{array}$ & $\begin{array}{l}\chi^{2} \\
\text { (A vs.D) }\end{array}$ & $\begin{array}{l}\chi^{2} \\
\text { B vs.C) }\end{array}$ & $\begin{array}{l}\chi^{2} \\
\text { (B vs.D) }\end{array}$ & $\begin{array}{l}\chi^{2} \\
\text { (C vs.D) }\end{array}$ \\
\hline $\begin{array}{l}\text { Positive influence: } \\
\text { Sympathy and } \\
\text { helping behaviour }\end{array}$ & $5 \%$ & $8 \%$ & $40 \%$ & $4 \%$ & ns & 16.13 & ns & 10.66 & ns & 14.82 \\
\hline $\begin{array}{l}\text { Positive model of } \\
\text { strong people }\end{array}$ & $28 \%$ & $27 \%$ & $11 \%$ & $5 \%$ & ns & ns & 9.54 & ns & 8.70 & 9.73 \\
\hline $\begin{array}{l}\text { Positive influence: } \\
\text { Experiences with } \\
\text { increase of tolerance }\end{array}$ & $31 \%$ & $30 \%$ & $10 \%$ & $10 \%$ & ns & 9.94 & 9.14 & ns & 7.51 & ns \\
\hline $\begin{array}{l}\text { Negative influence: } \\
\text { Insecurity about } \\
\text { peoples unpredictable } \\
\text { behavior and customs }\end{array}$ & $26 \%$ & $25 \%$ & $28 \%$ & $25 \%$ & ns & ns & ns & ns & ns & ns \\
\hline $\begin{array}{l}\text { Undirect positive } \\
\text { influence by music, } \\
\text { literature, movies etc }\end{array}$ & $10 \%$ & $10 \%$ & $11 \%$ & $56 \%$ & ns & ns & 37.98 & ns & 36.62 & 43.22 \\
\hline
\end{tabular}

\section{Conclusions}

This study follows a key aspect of sociocultural approaches - the focus on the situated nature of behavior and how it is socially constituted in the specific area of conceptualization of meaning of foreigners among university students. The meaning of foreigners among Estonian, Latvian, Lithuanian and Russian university students was generally conceptualized in society level as an exclusion of people with different nationality and language and marginalization of people. Braun, Behr and Kaczmirek (2013) analyzed the cross-national equivalence of the meaning of the term immigrants and found that the perception of immigrants was determined by a general representation of immigrants as well as a representation by the most dominant ethnic minority group, which differed from country to country. Also, Asbrock et al. (2014) found that the meaning of foreigners was dominantly connected with largest groups of people with migration background in the country. Our results indicated that university students conceptualized foreigners broader than ethnic minority group in society - excluded and marginalized people. Following sociocultural perspectives present study reveal that university students' understandings and interpretations of foreigners as socially contracted societal constructs differed somewhat - Russian respondents empathized more differences in citizenship and three Baltic states respondents in attitudes and values. Additionally, it was revealed that the meaning of foreigners for Estonian students was conceptualized more from individualistic, than collectivistic, perspective, supporting tendencies among young peoples' citizenship behavior (Krzywosz-Rynkiewicz et al., 2018).

All four countries university students were generally open and tolerant toward foreigners in individual differences evoked from cultural enrichment, but their attitudes showed some variation: Estonian students expressed more the attitude that people are equal; and Latvian, Lithuanian and Russian respondents were more prone to express positive attitude towards foreigners when there is mutual respect and common values. Thus, acceptance of foreigners of university students depends on the attitudes in the individual level, the unacceptance of the foreigners reflects the quality of opinions in the society level. Namely, negative attitudes toward foreigners among four groups of university students tended to be more pronounced against aggression, violence, discrimination and extremism in society, whereby the dominant reason for non-tolerance tended to be different - discrimination and extremism for three Baltic countries students, and not following of cultural traditions and rules for Russian students, showing an overall acceptances in the personal level, but un-acceptance in society level in terms of threatens of equality and security. Also, Sakai \& Koike (2015) found that university students' attitudes towards foreigners were confounding, but dominantly positive.

Although, university students tended to have tolerant attitudes towards foreigners, but ambivalent experiences concerning with influence of foreigners. Specifically, the influence of foreigners in terms of personal positive experiences for three Baltic counties students was direct and to Russian university students tended to be indirect; and at one side - negative personal experiences for most of the respondents related to insecurity evoked from peoples' unpredictable behavior and customs. Also, Kim (2004) found that college students' attitudes toward minorities were more influenced by subjective factors than by demographic characteristics and family backgrounds. Even though we analyzed data among four country university students' samples, we argue that our pilot study results are important for other countries as well, especially planning surveys for attitudes toward foreigners or immigrants, there is a challenge for specification of the meaning of main concept for the specific target group. 


\section{References}

Asbrock, F., Lemmer, G., Becker, J. C., Koller, J., \& Wagner, U. (2014). „Who are these foreigners anyway?" The content of the term foreigner and its impact on prejudice. SAGE Open, April-June, $1-8$.

Bisson, L. (2016). Russia's immigration policy: new challenges and tools. Russie.Nei.Visions, No.91. Paris: Ifri.

Braun, M., Behr, D., \& Kaczmirek, L. (2013). Assessing cross-national equivalence of measures of xenophobia: Evidence from probing in web surveys. International Journal of Public Opinion Research, 25, 383-395.

Condran, J. G. (1979). Changes in white attitudes toward blacks: 1963-1977. Public Opinion Quarterly, 43, 463-476.

Gang, I. N., Rivera-Batiz, F. L. \& Yun, M. S. (2013). Economic strain, education and attitudes towards foreigners in the European Union. Review of International Economics, 21(2), 177-190.

Gorodzeisky, A., \& Semyonov, M. (2009). Terms of exclusion: Public views toward admission and allocation of rights to immigrants in European countries. Ethnic and Racial Studies, 32, 401-423.

Hjerm, M. (2001). Education, xenophobia and nationalism: A comparative analysis. Journal of Ethnic and Migration Studies, 27(1), 37-60.

Kim, S. H. (2004). College students attitudes toward and social distance feelings toward minorities. Social Research, 1, 169-206.

Kovalenko, J. (2010). Situation of new immigrants in Estonia. In New immigrants in Estonia, Latvia and Lithuania (pp. 7-24). Tallinn, Estonia: Legal Information Centre for Human Rights.

Krzywosz-Rynkiewicz, B., Zalewska, A. M., Kõiv, K., Zuzeviciute, V., \& Vidnere, M. (2018). Young people citizenship activity in post-soviet states - comparison across countries. In: B. Krzywosz-Rynkiewicz, A. M. Zalewska, \&amp; K. J. Kennedy (Eds.). Young People and Active Citizenship in Post-Soviet Times: A Challenge for Citizenship Education (pp. 41-51). London and New York: Routledge, Taylor \& Francis Group.

Leončikas, T., \& Žibas, K. (2010). Situation of new immigrants in Lithuania. In New immigrants in Estonia, Latvia and Lithuania (pp. 41-73). Tallinn, Estonia: Legal Information Centre for Human Rights.

McLaren, L.M. (2003). Anti-immigrant prejudice in Europe: Contact, threat perception, and preferences for the exclusion of immigrants. Social Forces, 81(3), 909-36.

Mensah, P. (2010). Situation of new immigrants in Latvia. In New immigrants in Estonia, Latvia and Lithuania (pp. 25-40). Tallinn, Estonia: Legal Information Centre for Human Rights.

Organisation for Economic Co-operation and Development (OECD) (2015). International Migration Outlook, Paris: OECD Publishing.

Ostapczuk, M., Much, J., \& Moshagen, M. (2009). A randomized-response investigation of the education effect in attitudes towards foreigners. European Journal of Social Psychology, 39, 920-931.

Paas, T. \& Halapuu, V. (2012). Attitudes towards immigrants and the integration of ethnically diverse societies. Discussion Paper No. 2012-23. Tartu: NORFACE Migration.

Sakai, H., \& Koike, H. (2011). Implicitly and explicitly measured attitudes towards foreigners: A dual-process model perspective. JABAET Journal, 14/15, 39-58.

Scheepers, P., Gijberts, M., \& Coenders, M. (2002). Ethnic exclusionism in European countries: Public oppositions to civil rights for legal migrants as a response to perceived threat, European Sociological Review 18, 17-34.

Semyonov, M., Raijman, R., Gorodzeisky, A. (2008). Foreigners' impact on European societies: Public views and perceptions in a cross-national comparative perspective. International Journal of Comparative Sociology, 49, 5-29.

Torney-Purta, J., Lehmann, R., Oswald, H., \& Schulz, W. (2001). Citizenship and education in twenty-eight countries: Civic knowledge and engagement at age fourteen. Amsterdam: IEA.

Wagner, U., van Dick, R., Pettigrew, T. F., \& Christ, O. (2003). Ethnic prejudice in East and West Germany: The explanatory power of intergroup contact. Group Processes and Intergroup Relations, 6, 22-36. 